\title{
DETERMINAN KEPUTUSAN TRANSFER PRICING (STUDI PADA PERUSAHAAN MANUFAKTUR YANG TERDAFTAR DI BEI TAHUN 2011 S.D. 2014 )
}

\author{
Ja'far Shodiq; Kesi Widjajanti; Endang Rusdianti \\ jafarsh82@gmail.com
}

Program Magister Manajemen,Universitas Semarang,Semarang,Indonesia

\begin{tabular}{l} 
Info Artikel \\
\hline Sejarah Artikel: \\
Diterima \\
Disetujui \\
Dipublikasikan \\
\hline Keywords: \\
Terdiri atas 3 sampai 5 \\
kata dan/atau kelompok \\
kata. \\
Ditulis sesuai urutan \\
abjad \\
Antara kata kunci \\
dipisahkan oleh titik \\
koma (;).
\end{tabular}

\begin{abstract}
Abstrak
Fenomena globalisasi telah mendorong banyak perubahan pada perusahaan Perusahaan tidak membatasi kegiatan operasinya hanya di negeri sendiri dan menjadi Perusahaan Multinasional. Perusahaan multinasional seringkali menjalankan praktek transfer pricing. Transfer pricing merupakan kebijakan perusahaan dalam menentukan harga transfer suatu transaksi baik itu barang, jasa, harta tak berwujud, atau pun transaksi keuangan yang dilakukan oleh perusahaan. Transfer pricing bisa dilakukan antardivisi dalam satu perusahaan bisa juga antara dua atau lebih perusahaan yang mempunyai hubungan istimewa (berafiliasi). Praktek transfer pricing dulunya dilakukan perusahaan untuk menilai kinerja antar anggota atau divisi perusahaan. Seiring dengan perkembangan zaman praktek transfer pricing sering dipakai untuk memaksimalkan laba dan manajemen pajak

Hasil penelitian ini menunjukkan bahwa 1) Pajak berpengaruh terhadap keputusan transfer pricing 2) Struktur kepemilikan berpengaruh terhadap keputusan transfer pricing 3) Leverage berpengaruh tetapi tidak signifikan terhadap keputusan transfer pricing. Kemudian, Leverage tidak berfungsi sebagai intervening bagi pajak dan struktur kepemilikan. Penelitian ini menunjukkan bahwa Pajak yang di proksikan dengan Corporate Tax Rate (CTR) terbukti berkaitan erat dengan keputusan hutang jangka pendek perusahaan, demikian juga dengan struktur kepemilikan yang diproksikan dengan kepemilikan institusional berkaitan erat dengan kebijakan hutang perusahaan, dan keputusan transfer pricing melalui penjualan yang berkaitan erat dengan Debt to Asset Ratio (DAR) yang mencerminkan keberlangsungan usaha perusahaan (going concern).
\end{abstract}




\section{DETERMINANTS OF TRANSFER PRICING DECISION (STUDY IN MANUFACTURING COMPANIES LISTED IN INDONESIA STOCK EXCHANGE IN 2011 UNTIL 2014)}

\section{Abstract}

Globalization has prompted many changes in the companies. They does not restrict their operations only in their own country and become a Multinational Company. Multinational companies often practice transfer pricing. Transfer pricing is the company's policy in determining the transfer price was a good deal of goods, services, intangible assets, or financial transactions conducted by the company. Transfer pricing can be done between divisions within a company can also be between two or more companies related (affiliated). The practice of transfer pricing was formerly done by the company to assess the performance of the company or division among members. As time goes by, transfer pricing practices used to maximize profits and tax management.

The results of this study indicate that 1) Tax affect the transfer pricing decisions 2) The ownership structure affect the transfer pricing decisions 3) Leverage affect but not significant to transfer pricing decision. Then, Leverage has no function as intervening for tax and ownership structure.

This study shows that the tax proxied by Corporate Tax Rate (CTR) proved to be closely related to the decision short-term debt, as well as the ownership structure proxied by institutional ownership is closely related to the policy of corporate debt, and the decision of transfer pricing through the sale closely related to Debt to Asset Ratio (DAR), which reflects the company's business continuity (going concern). 


\section{PENDAHULUAN}

Fenomena globalisasi secara tidak langsung telah mendorong banyak perubahan pada perusahaan. Lahirnya World Trade Organization (WTO) menjadikan perusahaan tidak membatasi kegiatan operasinya hanya di negeri sendiri, akan tetapi merambah ke mancanegara dan menjadi perusahaan multinasional.

Perusahaan multinasional dengan lingkup usahanya yang borderless country akan mengahadapi beberapa permasalahan, salah satunya yaitu perbedaan tarif pajak. Perbedaan tarif pajak ini dapat membuat perusahan multinasional mengambil keputusan untuk melakukan transfer pricing.

Praktek transfer pricing dulunya dilakukan perusahaan untuk menilai kinerja antar anggota atau divisi perusahaan, tetapi seiring dengan perkembangan zaman praktek transfer pricing sering juga dipakai untuk memaksimalkan laba dan manajemen pajak yaitu untuk meminimalkan jumlah pajak yang harus di bayar oleh perusahaan (Mangoting, Yenni, 2000).

Penelitian pengaruh pajak terhadap keputusan transfer pricing telah dilakukan oleh peneliti di Indonesia, diantaranya penelitian oleh Ni Wayan Yuniasih, Ni Ketut Rasmini, Made Gede Wirakusuma (2012) yang menghasilkan kesimpulan pajak berpengaruh positif terhadap keputusan transfer pricing yang berarti bahwa semakin besar pajak yang dibayar perusahaan multinasional, semakin besar kemungkinan melakukan praktik transfer pricing. Hal tersebut sejalan dengan hasil penelitian Nancy Kiswanto dan Anna Purwaningsih (2014) akan tetapi bertolak belakang dengan hasil penelitian Marfuah, Andri Puren Noor Azizah yang menyatakan bahwa pajak berpengaruh negatif terhadap keputusan transfer pricing.

Leverage juga berpengaruh terhadap keputusan transfer pricing perusahaan. Leverage didefinisikan sebagai nilai buku total hutang jangka panjang dibagi dengan total aktiva. Leverage dapat bertindak sebagai pengganti untuk transfer pricing aggressiveness dalam mencapai pengurangan kewajiban pajak perusahaan. Penelitian sebelumnya oleh Bernard et al. (2006) menunjukkan bahwa perusahaan dengan leverage yang tinggi lebih agresif terhadap pajak perusahaan dengan rasio utang terhadap ekuitas yang rendah. Perusahaan multinasional biasanya membiayai anggota kelompok dengan transfer utang dan / atau modal (Richardson et al., 1998). Penelitan Richardson, Grant (2013) menyebutkaan bahwa leverage berpengaruh positif signifikan terhadap transfer pricing.

Selain pajak, keputusan perusahaan untuk melakukan transfer pricing juga dipengaruhi oleh struktur kepemilikan. Penelitian yang dilakukan oleh Dynaty, Utama, Rossieta, dan Veronica (2011) menunjukkan bahwa semakin tinggi hak kendali yang dimiliki pemegang saham pengendali, termasuk pemegang saham pengendali asing, memungkinkan pemegang saham pengendali untuk memerintahkan manajemen melakukan transaksi pihak berelasi yang bersifat merugikan pemegang saham non pengendali dan menguntungkan pemegang saham pengendali. Salah satu transaksi pihak berelasi yang dapat dilakukan adalah transfer pricing. 
Tabel 1.1.

Fenomena pada objek penelitian

\begin{tabular}{|l|l|l|}
\hline Tahun & $\begin{array}{l}\text { Rata-rata } \\
\text { transfer } \\
\text { pricing } \\
\text { penjualan }\end{array}$ & $\begin{array}{l}\text { Rata-rata } \\
\text { transfer } \\
\text { pricing } \\
\text { pembelian }\end{array}$ \\
\hline 2011 & 18.31 & 17.35 \\
\hline 2012 & 19.35 & 19.53 \\
\hline 2013 & 19.01 & 19.83 \\
\hline 2014 & 19.62 & 17.46 \\
\hline
\end{tabular}

Berdasarkan uraian diatas, terdapat beberapa variabel yang mempengaruhi transfer pricing seperti pajak, leverage, dan struktur kepemilikan. Yang membedakan dengan penelitian sebelumnya di Indonesia adalah penggunaan leverage sebagai variabel intervening dan penggunaan SEM untuk menganalisis. Penelitian ini diharapkan akan menambah pengetahuan bagi perkembangan ilmu pengetahuan dengan memberikan gambaran faktor yang mempengaruhi perusahaan mengambil keputusan untuk melakukan transfer pricing.

\section{RUMUSAN MASALAH}

Transfer pricing menjadi hal yang tak terhindarkan bagi perusahaan multinasional yang beroperasi secara borderless country. Transfer pricing manipulation merupakan suatu kegiatan untuk memperbesar biaya atau merendahkan tagihan yang bertujuan untuk memperkecil jumlah pajak yang terutang. Penelitian ini akan mengkaji mengenai faktor-faktor yang mempengaruhi keputusan perusahaan melakukan transfer pricing sehingga masalah yang akan diteliti dalam penelitian ini adalah:

1) Apakah pajak penghasilan mempengaruhi leverage?

2) Apakah pajak penghasilan mempengaruhi transfer pricing

3) Apakah struktur kepemilikan mempengaruhi leverage?

4) Apakah struktur kepemilikan mempengaruhi transfer pricing?

5) Apakah leverage mempengaruhi transfer pricing?

\section{TELAAH PUSTAKA}

\section{Teori Agensi}

Teori keagenan merupakan basis teori yang mendasari praktik bisnis perusahaan yang dipakai selama ini. Dalam teori keagenan (agency theory), hubungan agensi muncul ketika satu orang atau lebih (principal) memperkerjakan orang lain (agent) untuk memberikan suatu jasa dan kemudian mendelegasikan wewenang pengambilan keputusan kepada agent tersebut. Hubungan antara principal dan agent dapat mengarah 
pada kondisi ketidakseimbangan informasi (asymmetrical information) karena agen berada pada posisi yang memiliki informasi yang lebih banyak tentang perusahaan. Dengan asumsi bahwa individu-ndividu bertindak untuk memaksimalkan kepentingan diri sendiri, maka dengan informasi asimetri yang dimilikinya akan mendorong agen untuk menyembunyikan beberapa informasi yang tidak diketahui principal. Agen yang diberikan wewenang untuk mengelola aktiva perusahaan mempunyai insentif untuk melakukan transfer pricing dengan tujuan menurunkan pajak yang harus dibayar. Transfer pricing adalah harga yang terkandung pada setiap produk atau jasa dari satu divisi yang di transfer ke divisi yang lain dalam perusahaan yang sama atau antar perusahaan yang mempunyai hubungan istimewa. Transaksi transfer pricing dapat terjadi pada divisi-divisi dalam satu perusahaan, antar perusahaan lokal, atau perusahaan lokal dengan perusahaan yang ada di luar negeri. Menurut Pernyataan Standar Akuntansi Keuangan (PSAK) No. 7 Tahun 2010, pihak-pihak yang mempunyai hubungan istimewa adalah bila satu pihak mempunyai kemampuan untuk mengendalikan pihak lain, atau mempunyai pengaruh signifikan atas pihak lain dalam mengambil keputusan. Transaksi antara pihak-pihak yang mempunyai hubungan istimewa adalah suatu pengalihan sumber daya, atau kewajiban antara pihak-pihak yang mempunyai hubungan istimewa, tanpa menghiraukan apakah suatu harga diperhitungkan. Berdasarkan pernyataan diatas dapat disimpulkan bahwa transfer pricing dapat terjadi antar perusahaan atau antar divisi yang memiliki hubungan istimewa atau berelasi. Dimana transaksi pihak yang memiliki hubungan istimewa sebagai transaksi yang opportunis atau transaksi yang efisien, sebagai transaksi yang opportunis dalam hal transaksi dengan pihak berelasi dapat menyebabkan conflict of interest yang konsisten dengan agency theory (Jensen dan Meckling, 1976)

\section{Transfer Pricing}

Transfer pricing adalah harga yang terkandung pada setiap produk atau jasa dari satu divisi yang di transfer ke divisi yang lain dalam perusahaan yang sama atau antar perusahaan yang mempunyai hubungan istimewa. Transaksi transfer pricing dapat terjadi pada divisi-divisi dalam satu perusahaan, antar perusahaan lokal, atau perusahaan lokal dengan perusahaan yang ada di luar negeri (Yuniasih, Rasmini dan Wirakusuma, 2011). Transfer pricing diartikan sebagai nilai yang melekat pada pengalihan barang dan jasa yang terjadi pada suatu transaksi antara pihak yang mempunyai hubungan istimewa. Gusnardi (2009), menyebutkan bahwa perusahaan multinasional melakukan transfer pricing adalah untuk meminimalkan kewajiban pajak global perusahaan mereka. Kemudian menurut (Mangoting, Yeni, 2000), motivasi pajak dalam transfer pricing pada perusahaan multinasional tersebut dilaksanakan dengan cara sedapat mungkin memindahkan penghasilan ke negara dengan beban pajak terendah atau minimal dimana negara tersebut memiliki grup perusahaan atau divisi perusahaan yang beroperasi. Dalam praktek bisnis, transfer pricing sering dilakukan perusahaan multinasional yang berada satu grup dengan perusahaan tersebut. Transfer pricing merupakan salah satu bentuk penghindaran pajak yang dilakukan oleh perusahaan multinasional karena perusahaan multinasional memiliki perusahaan asing yang memungkinkan perusahaan melakukan transfer pricing. Berdasarkan Pasal 1 ayat (8) Peraturan Direktur Jenderal Pajak Nomor PER-43/PJ./2010 yang diubah terakhir dengan PER-32/PJ./2011, mendefinisikan penentuan harga transfer (transfer pricing) yaitu 
"penentuan harga dalam transaksi antara pihak- pihak yang mempunyai hubungan istimewa.

\section{Pajak}

Menurut Undang-Undang Nomor 16 Tahun 2009 Pajak adalah kontribusi wajib kepada negara yang bersifat memaksaberdasarkan Undang-Undang, dengan tidak mendapat kan imbalan secara langsung dan digunakan untuk keperluan negara bagi sebesar-besarnya kemakmuran rakyat. Sedangkan Menurut Undang Undang Nomor 7 Tahun 1983 sebagaimana telah diubah beberapa kali terakhir dengan Undang Undang Nomor 36 Tahun 2008 tentang Pajak Penghasilan, Pajak pengasilan diartikan sebagai Pajak yang dikenakan terhadap Subjek pajak atas penghasilan yang diterima atau diperoleh dalam tahun pajak. Subjek Pajak dalam hal ini adalah Perusahaan yang terdaftar sebagai Wajib Pajak pada Kantor Pelayanan Pajak.

Direktorat Jenderal Pajak telah mempunyai peraturan berkaitan dengan transaksi dengan pihak yang mempunyai hubungan istimewa yaitu PER-32/PJ./2011 yang mengatur:

a. Transfer pricing yang dilakukan oleh wajib pajak sesuai dengan prinsip kewajaran (arm's length principle)

b. Metodologi transfer pricing yang digunakan oleh wajib pajak sesuai dengan peraturan yang berlaku dan praktik usaha yang lazim yang tidak dipengaruhi hubungan istimewa;

c. Wajib pajak yang bersangkutan dan perusahaan afiliasinya telah membayar pajak sesusai dengan proporsi fungsinya dalam transaksi; serta

d. Mendokumentasikan penerapan prinsip kewajaran dan kelaziman usaha, dalam penentuan harga transaksinya. Untuk itu wajib pajak yang melakukan transaksi afiliasi wajib menyiapkan dokumentasi yang memadai untuk membuktikan bahwa transfer pricing yang dilakukan telah sesuai dengan arm's length principle (membuat TP Documentation).

\section{Leverage}

Leverage didefinisikan sebagai nilai buku total hutang jangka panjang dibagi dengan total aktiva. Leverage diprediksi memiliki hubungan positif dengan risiko, karena semakin besar leverage semakin besar kewajiban membayar dalam jangka panjang. Leverage mengukur seberapa besar perusahaan dibiayai dengan utang. Pada saat tingkat Leverage besar, maka laba yang dihasilkan akan dapat menutup pembayaran bunga dan pokok pinjaman. Namun jika tingkat leverage yang dihasilkan oleh suatu perusahaan kecil maka kecil pula kemampuan perusahaan untuk pembayaran bunga dan pokok pinjamannya. Maka dari itu, saat utang meningkat manajemen akan melakukan penyesuaian angka-angka akuntansi untuk menyepakati pembatasan-pembatasan seperti misalnya perjanjian hutang (Jensen dan Meckling 1976). Semakin besar utang maka akan berdampak terhadap profitabilitas yang diperoleh perusahaan, karena sebagian digunakan untuk membayar bunga pinjaman. Dengan biaya bunga yang semakin besar, maka profitabilitas (earnings after tax) semakin berkurang (karena sebagian digunakan untuk membayar bunga), maka hak pemegang saham (dividen) juga semakin berkurang. Bahkan pertimbangan pajak muncul untuk membuat utang menjadi pembiayaan dalam pajak tinggi dan ekuitas dalam pajak rendah (Richardson,Grant et al., 2013). Menurut 
Haron (2014) Leverage diukur dengan proksi Total Debt To Debt and Equity, Longterm Debt To Debt\& Equity ${ }_{2}$ Shortterm Debt To Debt\& Equity dan Debt to Asset Ratio.

\section{Struktur kepemilikan}

Struktur kepemilikan akan memiliki motivasi yang berbeda dalam memonitor perusahaan serta manajemen dan dewan direksinya. Struktur kepemilikan dipercaya memiliki kemampuan untuk mempengaruhi jalannya perusahaan yang nantinya dapat mempengaruhi kinerja perusahaan. Jensen dan Meckling (1976) menyatakan bahwa kepemilikan manajerial dan kepemilikan institusional adalah dua mekanisme corporate governance yang dapat mengendalikan masalah keagenan.

Struktur kepemilikan saham pada dasarnya adalah proporsi kepemilikan institusional, kepemilikan manajemen, dan kepemilikan asing dalam kepemilikan saham perusahaan Sajid Gul et. al (2012). Dalam menjalankan kegiatannya, suatu perusahaan diwakili oleh direksi (agents) yang ditunjuk oleh pemegang saham (principals) Sajid Gul, et al (2012). Penelitian Dynaty, et al (2011) menyebutkan bahwa kepemilikan pengendali akhir berpengaruh positif terhadap transaksi dengan pihak berelasi.

Sementara menuut Kiswanto (2014) entitas asing yang memiliki saham sebesar 20\% atau lebih dianggap memiliki pengaruh signifikan dalam mengendalikan perusahaan disebut sebagai pemegang saham pengendali asing. Pemegang saham pengendali asing dalam perusahaan yang stuktur kepemilikannya terkonsentrasi akan lebih mementingkan kesejahteraannya.

Dalam Pasal 1 ayat 8 UU Nomor 25 Tahun 2007 menyebutkan bahwa Modal Asing adalah modal yang dimiliki oleh negara asing, perseorangan warga negara asing, dan Badan Hukum Indonesia yang sebagian atau seluruh modalnya dimiliki oleh pihak asing. Mengacu pada pasal diatas maka dapat disimpulkan bahwa kepemilikan saham asing merupakan proporsi saham biasa perusahaan yang dimiliki oleh perorangan, badan hukum, pemerintah serta bagian-bagiannya yang berstatus luar negeri. Penggunaan hak kendali untuk memaksimalkan kesejahteraan pribadi dengan distribusi kekayaan dari pihak lain sering disebut sebagai ekspropriasi. Sebagai contoh, pemegang saham pengendali baik entitas dalam negeri maupun asing dapat mentransfer dana dan aset perusahaan lainnya untuk kepentingan dirinya sendiri. Caranya melalui praktek transfer pricing: pemegang saham pengendali menjual produk dari perusahaan yang ia kendalikan kepada perusahaan yang masih berafiliasi dengan harga yang tidak sewajarnya. 


\section{Kerangka pemikiran teoritis}

\section{Gambar 1}

\section{Kerangka Pemikiran Teoritis}
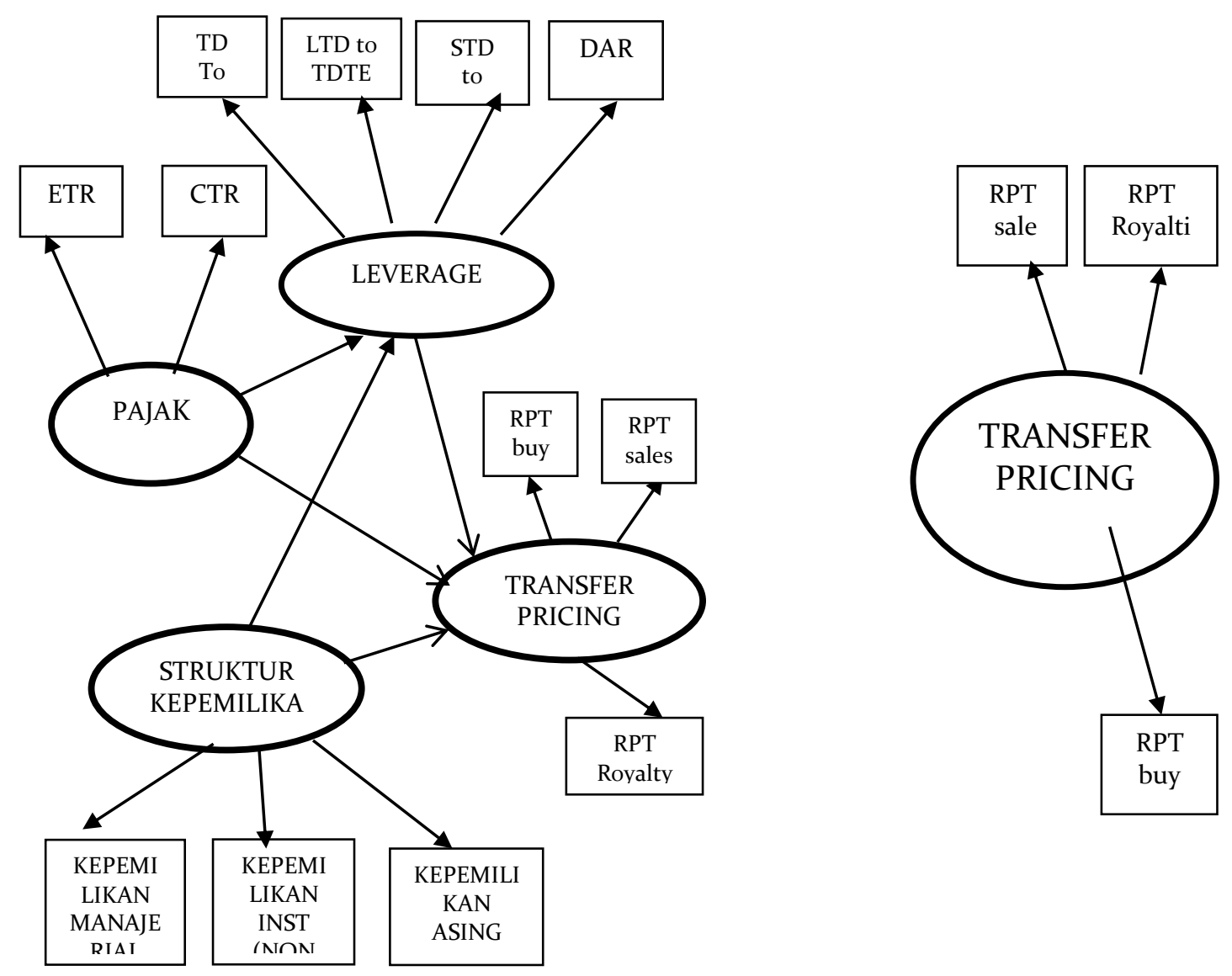

\section{Hipotesis penelitian}

H1: Pajak berpengaruh positif terhadap leverage

$\mathrm{H} 2$ : Pajak berpengaruh negatif terhadap transfer pricing

H3: Sruktur Kepemilikan berpengaruh negatif terhadap keputusan leverage

H4: Sruktur Kepemilikan berpengaruh positif terhadap keputusan transfer pricing

H5 : Leverage berpengaruh positif terhadap Transfer Pricing.

\section{METODE PENELITIAN}

\section{Jenis Penelitian}

Penelitian ini menggunakan jenis penelitian kuantitatif, yaitu metode penelitian yang berlandaskan pada falsafah positivisme, digunakan untuk meneliti pada populasi atau sampel tertentu. Teknik pengambilan sampel pada umumnya dilakukan 
secara random, pengumpulan data menggunakan instrumen penelitian, analisis data bersifat kuantitatif/statistik dengan tujuan untuk menguji hipotesis yang telah ditetapkan (Sugiyono, 2015). Metode ini disebut juga metode ilmiah (scientific) karena metode ini telah memenuhi kaidah-kaidah ilmiah yaitu konkrit, empiris, obyektif, terukur, rasional, dan sistematis.

Proses penelitian kuantitatif diawali dari studi pendahuluan dari obyek yang diteliti untuk menggali permasalahan yang ada. Selanjutnya masalah dirumuskan secara spesifik kemudian menjawab masalah yang bersifat sementara (hipotesis). Kemudian untuk menguji hipotesis dapat memilih metode/strategi/pendekatan/desain penelitian yang sesuai. Proses terakhir adalah kesimpulan penelitian serta saran/implikasi penelitian.

\section{Variabel Penelitian}

Menurut Hatch dan Farhady dalam Sugiyono (2015) variabel adalah segala sesuatu yang berbentuk apasaja yang ditetapkan oleh peneliti untuk dipelajari sehingga diperoleh informasi tentang hal tersebut, kemudian ditarik kesimpulannya.

\section{Variabel Dependen}

Variabel dependen adalah atau dalam bahasa Indonesia sering disebut sebagai variabel terikat merupakan variabel yang dipengaruhi atau menjadi akibat, karena adanya variabel bebas. Dalam SEM (Structural Equation Modelling) variabel dependen disebut juga variabel endogen (Sugiyono, 2105). Dalam penelitian ini, variabel dependen yang digunakan adalah transfer pricing. Transfer pricing diukur menggunakan proksi rasio nilai transaksi pihak berelasi (related party transaction/RPT), yang menurut PSAK no. 7 merupakan pengalihan sumber daya atau kewajiban antara pihak-pihak yang mempunyai hubungan istimewa, tanpa menghiraukan apakah suatu harga diperhitungkan. Pengukuran transfer pricing dalam penelitian ini adalah transaksi pembelian penjualan serta royalty, komisi, lisensi, franchise, sewa, imbalan atas jasa teknik dan imbalan atas jasa lainnya dengan pihak berelasi (Gusnardi, 2009)

\section{Variabel Independen}

Variabel independen dalam bahasa Indonesia sering disebut sebagai variabel bebas, merupakan variabel yang mempengaruhi atau menjadi sebab perubahannya atau timbulnya variabel dependen Dalam SEM (Structural Equation Modelling) variabel dependen disebut juga variabel eksogen (Sugiyono, 2105). Variabel independen dalam penelitian ini pajak, leverage dan struktur kepemilikan.

\section{Operasionalisasi Variabel}

Variabel akan diukur berdasarkan :

1. Pajak

Pajak merupakan Kontribusi wajib kepada negara yang terutang oleh orang pribadi atau badan yang bersifat memaksa berdasarkan undang-undang, dengan tidak mendapatkan imbalan secara langsung dan digunakan untuk keperluan negara bagi sebesar - besarnya kemakmuran rakyat. Pajak Penghasilan dalam penelitian ini diproksikan dengan Effective Tax Rate Yuniasih et al., ( 2012) dan Corporate Tax Rate sesuai dengan penelitian Maftukhah (2013) 


\section{Leverage}

Leverage merupakan sumber pendanaan perusahaan eksternal dari hutang, hutang yang dimaksud di sini adalah hutang jangka panjang. Dalam penelitian sebelumnya menyatakan bahwa perusahaan yang tinggi rasio utang terhadap ekuitas akan meminimalkan pajak perusahaan (Richardson, 2013). Salah satu variabel independen dalam penelitian ini adalah leverage. Banyak definisi mengenai leverage. Mengacu pada studi sebelumnya, definisi leverage yang berbeda akan menghasilkan suatu hasil yang berbeda. Menurut Haron (2014) leverage diukur dengan proksi Total Debt To Debt and Equity, Longterm Debt To Debt\& Equity, Shortterm Debt To Debt\& Equity dan Debt to Asset Ratio (DAR).

\section{Struktur Kepemilikan}

Struktur kepemilikan dalam penelitian ini diukur menggunakan kepemilikan asing menurut Kiswanto (2014), kepemilikan institusional dan kepemilikan manajerial (Sajid, 2012)

a. Kepemilikan asing

Kepemilikan asing diproksikan dengan persentase kepemilikan saham di atas 20\% sebagai pemegang saham pengendali. Kriteria struktur kepemilikan terkonsentrasi didasarkan pada UU Pasar Modal No. IX.H.1, yang menjelaskan pemegang saham pengendali adalah pihak yang memiliki saham atau efek yang bersifat ekuitas sebesar $20 \%$ atau lebih. PSAK No. 15 juga menyatakan tentang pengaruh signifikan yang dimiliki oleh pemegang saham dengan persentase 20\% atau lebih (Yuniasih, 2012).

b. Kepemilikan Institusional

Kepemilikan institusional menurut Darren Harry dalam Sajid (2012) diproksikan dengan persentase kepemilikan saham institusi terhadap jumlah seluruh saham. PSAK No. 15 juga menyatakan tentang pengaruh signifikan yang dimiliki oleh pemegang saham dengan persentase 20\% atau lebih (Yuniasih, 2012)

c. Kepemilikan Manajerial

Kepemilikan Manajerial menurut Darren Harry dalam Sajid Gul, et al (2012) diproksikan dengan persentase kepemilikan saham yang dimiliki dewan direksi terhadap jumlah seluruh saham

\section{HASIL DAN PEMBAHASAN}

\section{Hasil Penelitian}

\section{Hasil Pengujian Kelayakan SEM}

\begin{tabular}{|l|l|l|l|}
\hline Kriteria & $\begin{array}{c}\text { Cut off } \\
\text { Value }\end{array}$ & $\begin{array}{c}\text { Hasil } \\
\text { Analisis }\end{array}$ & $\begin{array}{c}\text { Evaluasi } \\
\text { Model }\end{array}$ \\
\hline $\begin{array}{l}\text { Chi- } \\
\text { Square }\end{array}$ & $\begin{array}{l}\text { Mende } \\
\text { kati nol }\end{array}$ & 28.979 & Baik \\
\hline
\end{tabular}




\begin{tabular}{|l|l|r|l|}
\hline $\begin{array}{l}\text { Probabi } \\
\text { lity } \\
\text { level }\end{array}$ & $\geq 0,05$ & .066 & Baik \\
\hline $\begin{array}{l}\text { CMIN/ } \\
\text { DF }\end{array}$ & $<2,000$ & 1.525 & Baik \\
\hline GFI & $\geq 0,900$ & 0.961 & Baik \\
\hline AGFI & $\geq 0,900$ & 0.907 & Baik \\
\hline CFI & $\geq 0,950$ & 0.986 & Baik \\
\hline TLI & $\geq 0,900$ & 0.973 & Baik \\
\hline $\begin{array}{l}\text { RMSE } \\
\text { A }\end{array}$ & $\leq 08$ & 0.060 & Baik \\
\hline
\end{tabular}

\section{Evaluasi atas sampel}

Sampel dalam penelitian ini adalah sebagian perusahaan manufaktur yang terdaftar di BEI anara tahun 2011 sampai dengan 2014 sebanyak 44 perusahaan selama 4 tahun, sehingga terdapat 176 data perusahaan. Ukurans ampel yang harus dipenuhi dalam pemodelan SEM minimum berjumlah 100 sampel dan selanjutnya menggunakan perbandingan 5 observasi untuk setiap parameter yang di estimasikan. Setelah melalui pengujian outlier jumlah sampel yang digunakan berjumlah 146. Pada penelitian ini jumlah parameter yang diestimasi sebanyak parameter, sehingga ampel minimum yang harus dipenuhi adalah 29 x 5 atau 145 sampel. Dengan jumlah sampel sebanyak 146 sudah mencukupi kriteria pemodelan SEM.

\section{Uji Normalitas Data}

Normalitas data juga perlu dilakukan pengujian. Pengujian ini dilakukan dengan mengamati nilai skewness data yangdigunakan, apabila nilai CR pada skewness data berada pada rentang antara $+/-2.58$ atau berada pada tingkat signifikansi 0.01 , Jika dihitung secara multivariate (berdasarkan data gabungan) tabel assessment of normality menunjukkan data 1.87 atau masih berada pada rentang yang diperkenankan. Dengan demikian, data penelitian yang digunakan telah memenuhi syarat normalitas data secara multivariate, atau dapat dikatakan bahwa data telah terdistribusi normal

\section{Uji Multivariate outlier}

Evaluasi terhadap mutivariate outlier dilakukan dengan memperhatikan nilai mahalonobis distance. Kriteria yang digunakan adalah berdasarkan chi square derajat kebebasan (degree of freedom) 19 yaitu jumlah variabel indikator pada tingkat signifikansi $\mathrm{p}<0.001$. Nilai mahalonobis distance $\mathrm{X}^{2}(19,001)=36.191$.

Nilai jarak mahalonobis terbesar (d-squared terbesar) yang dapat dilihat pada lampiran diketahui bahwa jarak mahalonobis maksimal adalah 25.905 (lebih kecil dari $36,191)$ sehingga dapat disimpulkan bahwa tidak terdapat outlier multivariate. Hasil 
pengujian menunjukkan tidak adanya outlier. Dengan demikian dapat disimpulkan tidak terdapat data yang ekstrim.

\section{Evaluasi atas multicollinearity atau singularity}

Multikolinearitas dapat dilihat melalui determinan matrik kovarian. Nilai determinan yang sangat kecil menunjukkan adanya indikasi multicollinearity atau singularity, sehingga data tidak dapat digunakan untuk penelitian. Dari hasil pengolahan data melalui AMOS 22 dapat diketahui determinan of sample covariance matrik sebesar 136552251165.333. Nilai tersebut sangat jauh dari nol, dengan demikian dapat dikatakan bahwa data penelitian yang digunakan tidak terdapat multikolinearitas dan singularitas.

\section{Interpretasi dan Modifikasi Model}

Evaluasi atas kesesuaian model yang diajukan dalam penelitian ini dengan beberapa kriteria goodness of fit yang telah diuraikan pada bab sebelumnya. Untuk mendapatkan tingkat kesesuaian yang memadai, model persamaan struktural pada penelitian ini telah di revisi dan di modifikasi. Revisi dan modifikasi dilakukan karena pada kesesuaian model pertama kriteria goodnes fit-nya belum mencukupi, revisi dilakukan setelah dianalisis pada text output pada item estimasi indikator (loading factor) menunjukkan nilai sangat rendah yaitu indikator untuk Struktur kepemilikan (KM) indikator untuk Struktur kepemilikan (LTD), dan indikator untuk transfer pricing (RPTbuy) peneliti merivisi model dengan memangkas 3 indikator tersebut. Untuk memperoleh model dengan kriteria goodness of fit sesuai kriteria diperlukan modifikasi. Pada sebuah model SEM yang telah dibuat dan diuji dapat dilakukan berbagai modifikasi. Tujuan modifikasi yang dilakukan dapat menurunkan chi square, seperti diketahui semakin kecilnya angka chi square menunjukkan semakin fit model tersebut dengan data yang ada (Singgih Santoso, 2015). Proses modifikasi sebuah model pada dasarnya sama dengan mengulang proses pengujian dan estimasi model. Pada AMOS 22 untuk modifikasi dapat dilakukan dengan mengaktifkan pilihan Modification Indices. Proses Modifikasi dilakukan dengan tahapan sebagai berikut:

1. Menghubungkan Indikator KA dengan Indikator ETR hal ini dimungkin kan karena adanya kepemilikan saham ssing pada sebuah entitas bisa mempengaruhi transaksi related party terutama penjualan untuk kepentingan perusahaan termasuk manajemen laba sehingga mempengaruhi rasio tarif pajak efektif (ETR) sesuai dengan penelitian Kiswanto (2014) menjelaskan bahwa Kepemilikan Asing berpengaruh terhadap transaksi penjualan piha berelasi yang pada akhirnya akan mempengaruhi pembayaran pajak (Effective Tax Rate).

2. Menghubungkan variabel struktur kepemilikan ke indikator SDtoTE, hal ini dimungkinkan karena Kepemilikan Perusahaan erat kaitannya dengan kebijakan hutang termasuk hutang jangka pendek, hal ini sesuai dengan penelitian Maftukhah (2013) yang menyatakan bahwa kepemilikan institusional baik asing maupun dalam negeri akan membuat pengawasan lebih optimal terhadap kebijakan hutang perusahaan. 
3. Menghubungkan indikator CTR terhadap SDtoTE, hal ini dimungkinkan karena salah satu pengukuran pajak yaitu CTR berkaitan erat dengan kebijakan hutang perusahaan termasuk hutang jangka pendek, hal ini sejalan dengan penilitian Maftukhah (2013) juga sejalan dengan teori Miller Modigliani yang menyatakan bahwa pada tingkat pajak yag tinggi, perusahaan cenderung menambah hutang (termasuk hutang jangka pendek) untuk mengurangi pajak (tax shield).

4. Menghubungkan indikator RPTsales ke indikator DAR, hal ini dimungkinkan karena berdasarkan penelitian Maftukhah (2013) menjelaskan bahwa tingginya penjualan (termasuk didalamnya penjualan dengan pihak berelasi) akan meningkatkan hutang perusahaan.

\section{Hubungan Kausalitas antar Variabel}

Uji statistik hubungan antar variabel yang menjadi dasar dalam hipotesisi penelitian telah dilakukan. Uji Statistik hasil pengoahan dengan SEM dilakukan dengan melihat tingkat signifikansi hubungan anatar variabel yang dapat dilihat melalui nilai significance probability masing-masing hubungan antar variabel. Proses pengujian statistik ini dapat dilihat pada tabel dibawah ini

\section{Regression Weight Structrural Equation Model}

\begin{tabular}{|c|c|c|c|c|c|c|}
\hline & & & $\begin{array}{c}\text { Esti } \\
\text { mat } \\
\mathrm{e}\end{array}$ & S.E. & C.R & $\mathrm{P}$ \\
\hline Leverage & $<-$ & Pajak & 16.4 & 7.79 & 2.11 & .035 \\
\hline Leverage & $\begin{array}{l}< \\
<-\end{array}$ & $\begin{array}{c}\text { Struktur } \\
\text { Kepemi } \\
\text { likan }\end{array}$ & $\begin{array}{c}- \\
.964\end{array}$ & .39 & 2.43 & .015 \\
\hline $\begin{array}{l}\text { Transfe } \\
\text { Pricing }\end{array}$ & $\begin{array}{l}< \\
<-\end{array}$ & Pajak & $\begin{array}{c}- \\
1.73\end{array}$ & .561 & $\begin{array}{c}- \\
3.09\end{array}$ & .002 \\
\hline $\begin{array}{l}\text { Transfer } \\
\text { Pricing }\end{array}$ & $\begin{array}{l}< \\
<-\end{array}$ & $\begin{array}{c}\text { Struktur } \\
\text { Kepemi } \\
\text { likan }\end{array}$ & .066 & .028 & 2.39 & .017 \\
\hline $\begin{array}{l}\text { Transfer } \\
\text { _Pricing }\end{array}$ & $\begin{array}{l}< \\
<-\end{array}$ & $\begin{array}{l}\text { Lever } \\
\text { age }\end{array}$ & .017 & .013 & 1.29 & .194 \\
\hline
\end{tabular}

Tabel tersebut menunjukkan bahwa hasil pengujian menunjukkan hampir semua variabel independen mempunyai pengaruh signifikan terhadap variabel dependennya.

\section{Pajak berpengaruh positif terhadap leverage}

Paramater estimasi untuk pengujian pengaruh pajak terhadap leverage menunjukkan nilai estimasi sebesar 16.439, dengan probabilitas 0.035. Nilai 
probabilitas memenuhi syarat penerimaan H1 karena lebih kecil dari 0.05 yang berarti signifikan. Dengan demikian dapat disimpulkan bahwa pajak berpengaruh positif signifikan terhadap leverage. Maka hipotesis ini diterima.

\section{Pajak berpengaruh negatif terhadap transfer pricing}

Paramater estimasi untuk pengujian pengaruh pajak terhadap transfer pricing menunjukkan nilai estimasi sebesar -1.739 , dengan probabilitas 0.002 Nilai probabilitas telah memenuhi syarat penerimaan $\mathrm{H} 1$ karena lebih kecil dari 0.05 yang berarti signifikan. Dengan demikian dapat dismpulkan bahwa pajak berpengaruh negatif signifikan terhadap transfer pricing. Maka hipotesis ini diterima.

\section{Struktur kepemilikan berpengaruh negatif terhadap leverage}

Paramater estimasi untuk pengujian struktur kepemilikan berpengaruh terhadap leverage menunjukkan nilai estimasi sebesar -0.964 , dengan probabilitas 0.015 . Nilai probabilitas telah memenuhi syarat penerimaan $\mathrm{H} 1$ karena lebih kecil dari 0.05 yang berarti signifikan. Dengan demikian dapat disimpulkan bahwa struktur kepemilikan berpengaruh negatif signifikan terhadap leverage. Maka hipotesis ini diterima

\section{Struktur kepemilikan berpengaruh positif terhadap transfer pricing}

Paramater estimasi untuk pengujian Struktur kepemilikan berpengaruh terhadap transfer pricing menunjukkan nilai estimasi sebesar 0.066 dengan probabilitas 0.17 Nilai probabilitas memenuhi syarat penerimaan $\mathrm{H} 1$ karena lebih besar dari 0.05 yang berarti signifikan. Dengan demikian dapat disimpulkan bahwa struktur kepemilikan berpengaruh positif signifikan terhadap transfer pricing. Maka hipotesis ini diterima.

\section{Leverage berpengaruh positif terhadap transfer pricing.}

Paramater estimasi untuk pengujian pengaruh leverage terhadap tranfer pricing menunjukkan nilai estimasi sebesar 0.017 , dengan probabilitas 0.194 . Nilai probabilitas tidak memenuhi syarat penerimaan $\mathrm{H} 1$ karena lebih besar dari 0.05 yang berarti tidak signifikan. Dengan demikian dapat dismpulkan bahwa leverage berpengaruh tapi tidak signifikan terhadap transfer pricing. Maka hipotesis ini ditolak.

\section{PEMBAHASAN}

Transfer pricing merupakan transaksi antara pihak-pihak yang mempunyai hubungan istimewa atau pihak terkait (berafiliasi). Pada prinsipnya transfer pricing adalah suatu pengalihan sumber daya, atau kewajiban antara pihak-pihak yang mempunyai hubungan istimewa, tanpa menghiraukan apakah suatu harga diperhitungkan. Transfer pricing dapat terjadi antar perusahaan atau antar divisi yang memiliki hubungan istimewa atau berelasi. Transfer pricing bisa menjadi transaksi yang oportunis atau transaksi yang efisien. Sebagai transaksi yang oportunis, transaksi dengan pihak berelasi dapat menyebabkan conflict of interest yang konsisten dengan agency theory (Jensen dan Meckling, 1976).

\section{Pengaruh pajak terhadap leverage}


Hasil pengujian hipotesis pertama diperoleh bahwa pajak berpengaruh positif signifikan terhadap leverage. Pada perusahaan manufaktur multinasional membiayai kegiatan perusahaan melalui hutang. Pembahasan tentang hutang tidak bisa lepas dari teori Modigliani dan Miller yang menyatakan bahwa perusahaan yang menggunakan hutang (leverage) dapat menaikkan nilai perusahaan. Peningkatan nilai perusahaan dikarenakan adanya perlindungan pajak yang berasal dari yang berasal dari pengurangan pajak atas bunga hutang.

Tarif pajak penghasilan di Indonesia yang diatur dengan Undang-undang nomor 18 Tahun 2008. Undang-undang tersebut mengatur bahwa bunga utang adalah beban yang dapat dikurangkan untuk tujuan perpajakan (tax deductible) Penerapan tarif pajak yang tinggi akan mendorong perusahaan untuk melakukan penghematan pembayaran pajak, yaitu salah satunya dengan jalan menambah utang. Hal tersebut menyebabkan pajak berpengaruh terhadap leverage (kebijakan hutang) perusahaan. Hasil penelitian ini menyatakan hubungan yang signifikan antara pajak dengan leverage. Penelitian ini memperkuat penelitian Maftukhah (2013).

\section{Pengaruh pajak terhadap transfer pricing}

Hasil pengujian hipotesis kedua diperoleh bahwa pajak berpengaruh signifikan negatif terhadap transfer pricing. Pada perusahaan manufaktur multinasional pajak menjadi alasan yang kuat untuk melakukan transfer pricing. Pajak menjadi alasan perusahaan untuk melakukan transfer pricing. Hasil ini mengindikasikan bahwa semakin meningkatnya pajak yang dikenakan maka perusahaan dalam melakukan transfer pricing dengan pihak yang mempunyai hubungan istimewa akan menurun. Hasil penelitian ini tidak sesuai dengan penelitian yang dilakukan oleh Yuniasih (2012) yang menemukan adanya pengaruh positif pajak terhadap keputusan transfer pricing. Hasil penelitian ini memperkuat penelitian sebelumnya yang dilakukan oleh Marfuah (2014) yang menyatakan bahwa otoritas fiskal (aparat perpajakan) secara subyektif memandang tujuan dilakukannya transfer pricing adalah untuk menghindari pajak. Dengan diadakannya kesepakatan pengaturan transfer pricing melalui regulasi antara wajib pajak dengan Direktorat Jenderal Pajak kepada pihak-pihak yang mempunyai hubungan istimewa maka dapat mengurangi terjadinya praktik penyalahgunaan transfer pricing oleh perusahaan multinasional.

Regulasi transfer pricing mengatur kedudukan Direktorat Jendral Pajak dengan pihak-pihak yang mempunyai hubungan istimewa (pihak yang melakukan transfer pricing). Peraturan Dirjen Pajak No.PER-42/PJ/2011. Aturan ini membahas tentang penerapan prinsip kewajaran dan kelaziman usaha (arm's length principal) terkait transaksi antara wajib pajak dengan pihak yang memiliki hubungan istimewa. Aturan ini mengharuskan wajib pajak untuk menggunakan nilai pasar wajar dalam bertransaksi dengan pihak istimewa (related parties). Apabila ada transaksi antar perusahaan yang memiliki hubungan istimewa maka kondisi transaksi tersebut harus sama dengan transaksi antar perusahaan yang tidak memiliki hubungan istimewa. Hal tersebut mengakibatkan pengaruh negatif pajak terhadap transfer pricing, penelitian ini mendukung penelitian Marfuah (2013). 


\section{Pengaruh struktur kepemilikan terhadap leverage}

Hasil pengujian hipotesis ketiga diperoleh bahwa struktur kepemilikan berpengaruh negatif signifikan terhadap leverage. Pada perusahaan manufaktur struktur kepemilikan yang dimiliki oleh institusi baik dalam dan luar negeri sangat berpengaruh terhadap kebijakan hutang perusahaan. Kebijakan hutang yang ditetapkan oleh manajemen perusahaan sangat tergantung pada bidang usaha dan karakter manajemen. Hasil penelitian ini mendukung penelitan Maftukhah (2013) yang telah dilakukan sebelumnya. Struktur kepemilikan dalam hal ini kepemilikan institusional berpengaruh signifikan terhadap leverage. Struktur kepemilikan merupakan presentase saham perusahaan yang dimiliki oleh investor institusional misalnya swasta, pemerintah (BUMN), maupun perusahaan asing. Kepemilikan oleh institusi maupun pihak asing akan mendorong peningkatan pengawasan yang lebih optimal terhadap kinerja manajemen terutama dalam pengambilan keputusan mengenai utang.

Dynaty (2011) menyatakan bahwa pemegang saham pengendali (asing dan institusional) menunjukkan pengaruh positif yang signifikan pada besaran transaksi pihak berelasi terkait aset dan transaksi pihak berelasi terkait utang. Hasil penelitian ini menunjukkan bahwa kehadiran investor institusional baik dalam negeri maupun asing memberi pengaruh yang signifikan terhadap kebijakan utang perusahaan yang terdaftar di Bursa Efek Indonesia. Hal ini berarti bahwa investor institutional sebagai pihak yang memonitor agen hanya sebatas mengawasi tindakan manajemen dan tidak berperan secara aktif dalam pengambilan keputusan mengenai utang. Pengaruh yang positif berarti semakin tinggi kepemilikan institusional maupun kepemilikan asing maka utang juga meningkat, kemungkinan disebabkan adanya alasan tertentu sehingga harus tetap meningkatkan utang, misalnya perusahaan hendak melakukan ekspansi usaha.

\section{Pengaruh struktur kepemilikan terhadap transfer pricing}

Hasil pengujian hipotesis keempat diperoleh bahwa struktur kepemilikan berpengaruh positif signifikan terhadap transfer pricing. Struktur kepemilikan perusahaan manufaktur yang dimiliki oleh institusi baik dalam negeri maupun institusi asing cenderung melakukan transaksi dengan pihak yang berelasi melalui transfer pricing untuk kepentingan pemegang saham baik termasuk untuk perencanaan pajak dan manajemen laba. Hasil penelitian ini mendukung penelitian penelitian Kiswanto (2014) serta Dynaty, et al (2011).

Dynanty (2011) menyatakan bahwa pemegang saham pengendali (institusional maupun asing) menunjukkan pengaruh positif yang signifikan terhadap transfer pricing. Dalam struktur kepemilikan yang terkonsentrasi pada institusi baik swasta, pemerintah, maupun pihak asing, saat kepemilikan saham yang dimiliki pemegang saham pengendali asing semakin besar, pemegang saham pengendali asing memiliki kendali yang semakin besar dalam menentukan keputusan dalam perusahaan yang menguntungkan dirinya termasuk kebijakan penentuan harga maupun jumlah transaksi transfer pricing. Hal ini dimungkinkan bahwa kepemilikan saham yang terkonsentrasi pada institusi baik swasta, peerintah maupun asing dapat mempengaruhi banyak sedikitnya transfer pricing yang terjadi. 
Ketika pihak institusi telah menanamkan modalnya pada perusahaan publik di Indonesia dengan persentase lebih dari $20 \%$ maka institusi tersebut bisa memberikan pengaruh signifikan terhadap keputusan yang dibuat perusahaan termasuk keputusan transfer pricing. Dengan demikian semakin besar kepemilikan oleh institusi baik swasta pemerintah maupun asing dalam suatu perusahaan maka semakin tinggi pengaruh pihak asing dalam menentukan banyak sedikitnya transfer pricing yang dilakukan. Adanya peraturan tentang transfer pricing di DJP menyebabkan Wajib Pajak (termasuk perusahaan yang melakukan transfer pricing) yang sahamnya dikuasai oleh institusi baik asing maupun dalam negeri harus menerapkan prinsip kewajaran usaha.

\section{Pengaruh leverage terhadap transfer pricing}

Hasil pengujian hipotesis kelima diperoleh bahwa leverage berpengaruh positif tidak signifikan terhadap transfer pricing. Terdapat indikasi pada perusahaan manufaktur multinasional menggunakan leverage yang erat kaitannya dengan kebijakan hutang perusahaan dengan mengadakan hutang antar pihak berelasi untuk menggantikan transfer pricing untuk kepentingan perusahaan seperti perencanaan pajak maupun manajemen laba. Hasil penelitian ini tidak mendukung penelitian Richardson ( 2013).

Leverage berpengaruh tetapi tidak signifikan terhadap transfer pricing disebabkan adanya Undang-undang Pajak Penghasilan RI mengatur besarnya rasio antara utang dan modal Wajib Pajak. Apabila rasio tersebut melebihi besarnya perbandingan yang ditetapkan dalam peraturan tersebut, maka biaya pinjaman yang dapat diperhitungkan dalam menghitung penghasilan kena pajak adalah sebesar biaya pinjaman sesuai dengan besarnya perbandingan yang telah ditetapkan antara biaya pinjaman dan hutang. Besarnya biaya pinjaman sesuai dengan perbandingan utang dan modal juga wajib memperhatikan ketentuan Pasal 6 dan Pasal 9 UU PPh.

Pasal 18 ayat 1 Undang-undang PPh menyebutkan bahwa Menteri Keuangan berwenang mengeluarkan keputusan mengenai besarnya perbandingan hutang dan modal perusahaan untuk kepentingan pajak, dalam penjelasan pasal tersebut mengatur semua pinjaman termasuk pinjaman terkait pihak yang mempunyai hubungan istimewa (berelasi). Hal tersebut menjadikan Hasil Penelitian ini tidak mendukung penelitian Richardson (2013)

\section{KESIMPULAN dan IMPLIKASI}

\section{Kesimpulan}

Berdasarkan hasil analisis data dan pembahasan yang telah dilakukan, maka kesimpulan yang dapat diambil dari penelitian ini adalah sebagai berikut :

1. Berdasarkan hasil pengujian pertama, bahwa pengujian tersebut menunjukkan pengaruh negatif antara pajak dan leverage.

2. Berdasarkan hasil pengujian kedua, bahwa pengujian tersebut menunjukkan pengaruh positif antara pajak dan transfer pricing. 
3. Berdasarkan hasil pengujian ketiga, bahwa pengujian tersebut menunjukkan pengaruh negatif antara struktur kepemilikan dan leverage.

4. Berdasarkan hasil pengujian keempat, bahwa pengujian tersebut menunjukkan pengaruh positif antara struktur kepemilikan dan transfer pricing.

5. Berdasarkan hasil pengujian kelima, bahwa pengujian tersebut menunjukkan pengaruh tidak signifikan antara leverage dan transfer pricing.

\section{Implikasi}

\section{Implikasi teoritis}

1. Pajak berpengaruh negatif signifikan terhadap keputusan transfer pricing pada perusahaan manufaktur yang terdaftar di BEI tahun 2011 s.d. 2014. Hal ini sesuai dengan penelitian Marfuah (2014) yang menyatakan bahwa Pajak berpengaruh negatif signifikan terhadap keputusan transfer pricing dan bertentangan dengan penelitian Kiswanto (2014) yang menyatakan Pajak dan kepemilikan asing berpengaruh positif terhadap transfer pricing serta Yuniasih (2012) yang menyatakan pajak, dan tunneling berpengaruh positif terhadap keputusan transfer pricing yang dilakukan oleh perusahaan.

2. Leverage berpengaruh positif tidak signifikan terhadap keputusan transfer pricing pada perusahaan manufaktur yang terdaftar di BEI tahun 2011 s.d. 2014. Hal ini tidak sesuai dengan penelitian Richardson (2013) yang menyatakan bahwa leverage dapat bertindak sebagai pengganti untuk transfer pricing dalam mencapai pengurangan kewajiban pajak perusahaan grup.

3. Struktur kepemilikan berpengaruh positif signifikan terhadap keputusan transfer pricing pada perusahaan manufaktur yang terdaftar di BEI tahun 2011 s.d. 2014. Hal ini sesuai dengan penelitian Dynaty (2011) yang menyatakan bahwa semakin tinggi hak kendali yang dimiliki pemegang saham pengendali, termasuk pemegang saham pengendali asing, memungkinkan pemegang saham pengendali untuk memerintahkan manajemen melakukan transaksi pihak berelasi, serta penelitian Kiswanto (2014) yang menyatakan bahwa entitas asing yang memiliki saham sebesar $20 \%$ atau lebih dianggap memiliki pengaruh signifikan dalam mengendalikan perusahaan dalam melakukan transfer pricing.

\section{Implikasi Manajemen}

Berdasarkan uraian yang telah dijabarkan pada bab sebelumnya, implikasi manajerial yang dapat diambil adalah:

1. Pemerintah dalam hal ini Direktorat Jenderal Pajak lebih mengetatkan pelaksanaan dari peraturan tentang transfer pricing yaitu peraturan PER-32/PJ/2011 tentang Penerapan Prinsip Kewajaran dalam Transaksi Hubungan Istimewa agar perusahan yang melakukan praktek transfer pricing benar-benar menerapkan kegiatan transfer 
pricing berdasarkan harga wajar. Hal ini dimaksudkan agar perusahaan mengurangi penyalahgunaan transaksi transfer pricing, sehingga pendapatan negara dari sektor perpajakan tidak berkurang.

2. Analis laporan keuangan menyadari bahwa pajak, leverage dan struktur kepemilikan mempengaruhi keputusan transfer pricing sehingga mampu menghasilkan analisa yang handal dan bisa dipertanggungjawabkan.

3. Manajemen perusahaan hendaknya menerapkan prinsip kewajaran transaksi atas keputusan transfer pricing yang di lakukan agar laporan keuangan mencerminkan kondisi yang sebenarnya.

4. Investor atau kreditor sebagai salah satu pihak yang memanfaatkan laporan keuangan perusahaan memahami bahwa transfer pricing dipengaruhi oleh pajak, leverage dan struktur kepemilikan. Dengan pengetahuan tersebut, investor atau kreditor tidak salah dalam mengambil keputusan.

\section{Keterbatasan Penelitian}

Keterbatasan pada penelitian ini adalah distribusi data pada sampel penelitian tidak semuanya normal untuk masing-masing variabel, walaupun secara keseluruhan (multivariate) sudah normal dan sudah pada kisaran cut off value yang ditentukan.

\section{Agenda Penelitian Yang Akan Datang}

Mengingat kelemahan dan keterbatasan penelitian ini agenda penelitian yang akan datang yang disarankan penulis adalah sebagai berikut:

1. Menambah variabel penelitian yaitu faktor-faktor yang mempengaruhi keputusan transfer pricing, mengingat adjusted $\mathrm{R}^{2}$ (koefisien determinasi) hanya sebesar 40.1\%. Terdapat faktor lain yang belum diteliti seperti efek perjanjian pajak berganda, jumlah anak perusahaan di luar negeri.

2. Menambah jumlah sampel perusahaan yang melakukan transfer pricing pada sektor lainnya, tidak terbatas pada sektor manufaktur seperti properti dan real estate, pertanian, pertambangan, keuangan, perdagangan dan sektor lainnya.

3. Estimasi pada penelitian ini menggunakan SEM yang relatif masih baru dan membutuhkan data yang terdistribusi normal dan bebas dari outlier. Penelitian di masa yang akan datang bisa dipertimbangkan untuk menggunakan teknik analisis yang tidak mensyaratkan data terdistribusi normal dan bebas dari outlier.

4.

\section{DAFTAR PUSTAKA}

Bernard, Andrew B, 2006, Transfer Pricing By US Based Multinational Firm, JEL Classification.

Dynaty, Vera, Sidharta Utama, Hilda Rossieta dan Sylvia Veronica, 2011, Pengaruh Kepemilikan Pengendali Akhir Terhadap Transaksi Pihak Berelasi, diakses dari asp.trunojoyo.ac.id pada tanggal 5 April 2016 
Gul, Sajid. Agency Cost, Corporate Governance and Ownership Structure (The Case of Pakistan), 2012, International Journal of Business and Social Science, Vol.3 No. 09.

Gusnardi.Penetapan Harga Transfer Dalam Kajian Perpajakan, 2009, Pekbis Jurnal, Vol.1, No.1.

Ghozali, Imam, 2011, Model Persamaan Struktural Konsep dan Aplikasi dengan Program AMOS 22. Semarang: Badan Penerbit Universitas Diponegoro.

Ghozali, Imam, 2011, Aplikasi Analisis Multivariate dengan Progam IBM SPSS19. Semarang: Badan Penerbit Universitas Diponegoro.

Haron, Razali. Capital Structure Inconclusiveness: Evidence Fom Malaysia, Thailand and Singapore. 2014 .International Jounal Of Managerial Finance. Vol.10 No.1

http://www.jonathansarwono.info/amos/amos.html

http://www.idx.co.id

Jensen, Michael C., William H. Meckling, 1976, Theory of The Firm: Managerial Behavior, Agency Costs and Ownership Structure, Journal of Financial Economics, No.4 pp. 305-360

Kiswanto, Nancy. 2014. Pengaruh Pajak, Kepemilikan Asing, dan Ukuran Perusahaan terhadap Transfer Pricing pada perusahaan Manufaktur di BEI Tahun 20102013. Diakses dari google.co.id pada tanggal 20 Juni 2016.

Klassen, Kenneth, Mark Lang, and Mark Wolfson, 1993, Geographic Income Shifting by Multinational Corporation in Response to Tax Rate Change. Journal of Accounting Research, Vol 31, pp 141-173.

Marfuah, Andri Puren Noor Azizah, 2014, Pengaruh Pajak, Tunneling Incentive dan Exchange Rate, JAAI Volume 18 No.2, Desember 2014: 156:165

Maftukhah, Ida, 2013, Kepemilikan Manajerial, Kepemilikan Institusional, Dan Kinerja Keuangan Sebagai Penentu Struktur Modal Perusahaan, JDM Vol. 4, No. 1, 2013, pp: 69-81

Mangoting, Yenni, 2000, Aspek Perpajakan Dalam Praktik Transfer Pricing, Jurnal Akuntansi dan Keuangan, Vol. 2, No. 1, Mei, hal. 69-82

Noviastika, F, Yuniadi Mayowan, Suhartini Karjo, 2016, Tunneling Incentive dan Good Corporate Governance (GCG) Terhadap Indikasi Melakukan Transfer Pricing Pada Perusahaan Manufaktur Yang Terdaftar Di Bursa Efek Indonesia (Studi Pada Bursa Efek Indonesia Yang Berkaitan Dengan Perusahaan Asing), Jurnal Perpajakan (JEJAK) Vol. 8 No. 1

Peraturan Direktur Jenderal Pajak Nomor PER-32/PJ/2011 tentang Penerapan Prinsip Kewajaran dan Kelaziman Usaha dalam Transaksi Antara Wajib Pajak dengan Pihak yang Mempunyai Hubungan Istimewa

Pernyataan Standar Akuntansi Keuangan (PSAK) Nomor 7 tentang Pengungkapan Pihak-Pihak yang Mempunyai Hubungan Istimewa

Rego, Sonja Olhoft, 2003, Tax Avoidance Activities of U.S, Multinational Corporations, University of Iowa. Diakses dari http:www.google.com pada tanggal 16 Mei 2016 
Richardson, Grant and Taylor, Grantley and Lanis, Roman, 2013, Determinants of Transfer Pricing Agressiveness: Empirical Evidence From Australian Firms. Journal of Contemporary Accounting and Economics. 9 (2): pp. 136-150.

Santoso, Singgih. AMOS 22 untuk Structural Equation Modelling. 2015. PT Elex Media Komputindo, Jakarta.

Setiawan, Hadi, Transfer Pricing dan Risikonya Terhadap Penerimaan Negara, 2013. diakses dari www.perpustakaan.kemenkeu.go.id pada tanggal 25 April 2016

Siregar, Sylvia Veronica N. P. dan Siddharta Utama, 2005, Pengaruh Struktur Kepemilikan, Ukuran Perusahaan, dan Praktik Corporate Governance Terhadap Pengelolaan Laba (Earnings Management), Simposium Nasional Akuntansi VIII.

Sugiyono, 2015, Metode Penelitian Pendidikan, Bandung: Alfabeta.

Undang-Undang Nomor 25 Tahun 2007 tentang Penanaman Modal.

Undang-Undang Nomor 16 Tahun 2009 tentang Ketentuan Umum dan Tata Cara Perpajakan.

Undang-Undang Nomor 36 Tahun 2008 tentang Pajak Penghasilan

Waluyo, Minto, 2007, Teknik Analisis Data Multivariat dengan Structural Equation Modelling (SEM), diakses dari situs http://www. ejournal.upnjatim.ac.id pada tanggal 24 Mei 2016.

Yuniasih, Ni Wayan, Ni Ketut Rasmini dan Made Gede Wirakusuma, 2011, Pengaruh Pajak dan Tunneling Incentive Pada Keputusan Transfer Pricing Perusahaan Manufaktur Yang Listing Di Bursa Efek Indonesia, Simposium Akutansi Nasional 2013. 